most obvious and natural setting for general practice based on proper premises, good equipment, and well-organized staff, almost all health centres will find themselves playing a rapidly increasing part in medical education. Such training programmes will need properly designed premises if they are to be effectively carried out. Some consulting-rooms will have to be larger, so that one or two students can sit in at the trainer's sessions ; extra consulting-rooms will have to be provided, because of the time taken over teaching; while a small conference or seminar room will be required for more formal teaching and discussions.

Clearly the keynote in designing future health centres will have to be flexibility to enable changes to be made within an existing building or extra rooms to be added to it. Another possibility is to build a health centre adjacent to a postgraduate medical centre attached to a district general hospital. This proximity would solve many of the problems of accommodation for students. For general practitioners it would make access to diagnostic facilities much easier. More generally it would enable them to collaborate with their hospital colleagues on equal terms.

\section{Beyond the Bounds}

Both the President of the General Medical Council, Lord Cohen of Birkenhead, and the Executive Committee of the International Society of Cardiology have made statements about the publicity surrounding some of the recent transplantation operations. Lord Cohen, in his presidential address on 28 May, $^{1}$ was particularly concerned to remove any doubts about the nature of the professional offence of advertising. It can arise from the publication (in any form) of matter directing attention to a doctor's professional skill, knowledge, services, or qualifications when the doctor concerned has "procured or sanctioned such publication primarily or to a substantial extent" for the purpose of obtaining patients or promoting his own professional advantage. $^{2}$ But before giving this reminder of the ethical position Lord Cohen drew attention to the criticism some of the personal publicity accompanying these dramatic operations had provoked, both in Parliament and elsewhere, "in terms of good taste and propriety." In so doing, he was voicing a general conviction that behaviour short of what it is the duty of the G.M.C. to inquire into can yet damage the profession's good name.

Intended primarily for cardiological journals, the statement by the Executive Committee of the International Society of Cardiology is outspoken. It deplores the fact that in recent times medical and surgical advances have become matters of public entertainment and even sensationalism. "Such a trend can only bring discredit to the profession as a whole," as well as raising false hopes in those not equipped to judge the implications of new developments. "While it is not possible to control the behaviour of those who seek instant publicity," the statement continues, the Council of the International Society feels a lead must be given by responsible members

\footnotetext{
1 Brit. med. 7. Suppl., 1968, 2, 193.

2 General Medical Council: 'Functions, Procedure, and Furisdiction. London. 1968.
}

of the profession. It strongly suggests, " as one method of ensuring more ethical behaviour and avoiding extremes of anxiety and misplaced hope," that new procedures should not be detailed in the lay media before they have been fully evaluated scientifically in reputable medical journals.

Coming from the source it does this advice will command respect. First publication of medical advances should be to the profession through the medical press, where the implications can be knowledgeably debated. There is, of course, a wholly understandable and legitimate public interest in these marvels of medical progress, and the various information media inevitably seek to satisfy the lay thirst for news. But it is time to call a halt when the traditional discretion which governs the relationship between doctor and patient to the benefit of both is put in jeopardy. Difficult though it may be, doctors concerned with cases likely to excite publicity should do all in their power to prevent the publicity getting out of hand. The examples of the Cambridge and Edinburgh transplant teams show that this can be achieved.

A profession is rightly jealous of its reputation, and traditionally seeks itself to curb behaviour which may do it harm. That cardiologist should speak to cardiologist about heart transplants is therefore specially appropriate. The Council of the International Society of Cardiology has put the profession in its debt.

\section{Colonel Henry Shortt, F.R.S.}

It was characteristic of the life which Colonel Shortt has led that when his colleagues, pupils, and friends wished to present a Festschrift in celebration of his eightieth birthday they had to wait until well into his eighty-second year before holding the ceremony because he was absent in tropical Africa carrying on successful researches on the tick cycle of canine piroplasmosis.

This redoubtable research worker has made fundamental contributions to our knowledge of two of the most widespread tropical infections-namely, visceral leishmaniasis (kala-azar) and malaria. As an officer of the Indian Medical Service he proved the transmission by sandflies of the former disease, and as $\mathrm{r}^{-}$,fessor of parasitology in the University of London he led the team which discovered the hitherto unknown liver cell phase in the life cycle of malaria parasites, ${ }^{1-4}$ introducing in fact the Shortt-Garnham tricycle with all its implications for our understanding of the mechanisms of recrudescence and relapse.

Since his "retirement" at the statutory age of 65 he has done more than any other single individual to render " technical assistance" to Commonwealth territories oversea, spending the greater part of 15 years under the auspices of the Colombo Plan, the Royal Society, and other bodies in providing personal aid and example to the peoples of tropical lands. In the intervals at home he has carried on and now continues research work at the Winches Farm Field Station of the London School of Hygiene and Tropical Medicine.

Shortt, H. E., and Garnham, P. C. C., Nature (Lond.), 1948, 161, 126. Shortt, H. E., Garnham, P. C. C., and Malamos, B., Brit. med. F., $1948,1,192$.

s Shortt, H. E., Garnham, P. C. C., Covell, G., and Shute, P. G., Brit. med. F., 1948, 1, 547.

Shortt, H. E.. and Garnham, P. C. C., Brit. med. F., 1948, 1, 1225. 